temperature than is generally done. By proceeding in this manner some portions can be converted into yellowcoloured brass, and other parts remain pure copper.

The contrasts between copper and brass are very marked,

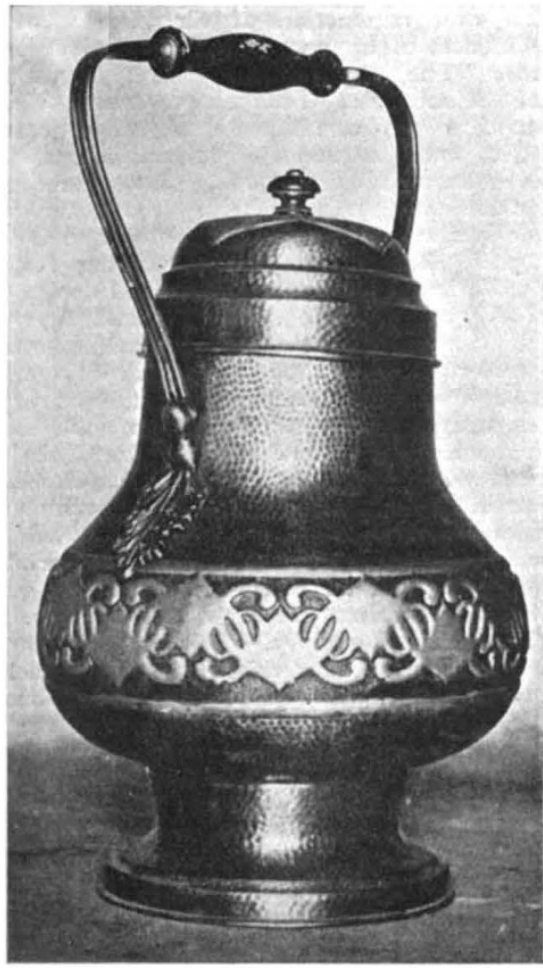

FIG. 4. - Copper and brass coal vase inlaid with zinc.

but softer effects can be obtained with zinc, aluminium, tin, and other metals. Fig. 4 shows such an inlaid copper vase.

One beauty about this process of inlaying metals which differentiates it from other processes is the soft transition which shades the inlaid metal from the surrounding metal. For instance, it will be observed that when inlaying zinc into copper, the zinc is surrounded by a halo of the brass-coloured alloy.

Mr. Cowper-Coles has also another process, which he calls Cowperising, and in which he uses vapour of zinc: the articles to be coated are not brought into contact with dry or molten zinc, but are placed in a chamber into which zinc vapour is passed. The chamber or drum is slowly rotated inside an outer cylinder in which the metallic zinc is heated by means of a gas or electric furnace. Hydrogen gas is also passed into the apparatus from a tube, and a pilot light is kept burning to make sure that air is not being sucked back.

The process has been found successful for decorating porcelain and metallic surfaces with a brilliant coating of zinc. The remarkable part about the action of zinc powder upon metals is the manner and speed with which it, at temperatures much below its melting point, sinks into and alloys with them. In this, Sherard-

ising rather resembles Sir W. Roberts-Austen's experiment in which he placed pieces of gold and lead together, and showed that diffusion took place even at ordinary temperatures; in his case, however, the diffusion was

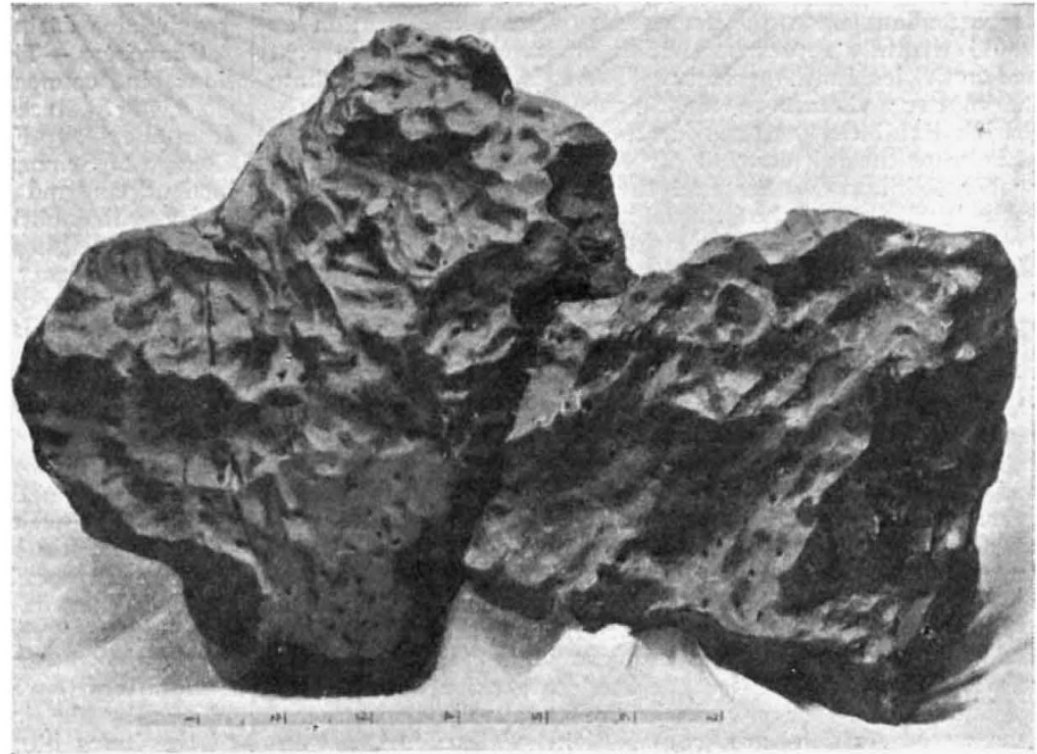

Mass produced by joining the two individuals of the Chupaderos meteorite. $x_{3}$ very slow. But with the Sherardising process the zinc sinks in in a few minutes to an appreciable depth Another peculiarity is that the zinc does not require to be pure, but is the commercial dust which is coated with oxide, and with this zinc dust I have found that it is practically impossible to get an electric current to pass through even a centimetre thickness, although 100 volts pressure was employed. Cadmium and a few other metals can also be employed, but they are not so satisfactory as zinc.

It looks as if the zinc has a very distinct vapour pressure even a very long way below its melting point, not to say its boiling point. The zinc vapour being immediately able to alloy with the iron or other metal in contact with it, equilibrium is destroyed, and a further portion of the zinc becomes vaporised.

F. M. P.

\section{STUDIES OF SOME AMERICAN METEORITES}

THE large crater, three-quarters of a mile across and 500 feet in depth, near Canyon Diablo, in Arizona, which it is supposed was produced by the impact of an enormous meteorite, has already been described at some length in Nature (I906, vol. Ixxiv., p. 490). Since that date the locality has been visited by Dr. George P. Merrill, of the United States National Museum, and in a paper published in the Smithsonian Miscellaneous Collections (roos, vol. I, pp. $46 \mathrm{I}-90$, with fifteen plates) he gives the results of his observations, and reviews the evidence for and against the meteoric hypothesis. In the hope of finding a large mass of metallic nickel-iron, Messrs. D. M. Barringer and B. C. Tilghman have made a detailed examination of the crater, and have put down a number of bore-holes to the depth of IIoo feet in its floor. Beneath the surface débris from the sides of the crater there is a thick bed of lake deposits; this lies on a crushed and pulverised sandstone containing fused and pumiceous fragments and particles of nickel-iron, while at a depth of about 600 feet the undisturbed red sandstone of the district was met with. No large mass of meteoric iron was encountered; and with the exception of four small pieces, the numerous masses of Canyon Diablo meteoric iron have all been found outside the crater. All the evidence undoubtedly points to the crater having been formed by the impact of a meteorite.
Prof. O. C. Farrington, in his "Meteorite Studies,

$$
\text { No. 2016, vol. } 78]
$$


tinents, most of which have been previously described, though one, an iron from Lampa, in Chile, is now described for the first time. The paper is illustrated with fifteen excellent plates of photographic reproductions; special attention may be directed to those representing the large masses of meteoric iron mounted in the School of Mines in the city of Mexico, which, though long known, do not appear hitherto to have been figured. The two masses of the Chupaderos iron, found at a distance of about 800 feet apart, and known in Mexico since 1852 , evidently formed part of the same mass, the total weight of which would have been about twenty-one tons. Particulars are also given respecting the fall of stones near Modoc, in Kansas, on September 2, 1905; fifteen stones with an aggregate weight of $35 \mathrm{lb}$. were found over an area of seven by two miles, the several masses gradually increasing in size from west to east, this being the direction in which the meteor fell. The same distribution of the stones according to size is noted in the fall at Weston, in Connecticut, in the year 1807 .

\section{THE SCIENCE COURT OF THE FRANCO- BRITISH EXHIBITION.}

A LL international exhibitions have contributed in some measure to the advancement of science. The assembling before the public of a great array of machinery has from time to time acted as a stimulus to inventions in which science was applied to promote safety, comfort, or luxury. The competition between manufacturers of scientific apparatus, encouraged by medals and other awards of excellence, doubtless resulted in improved workmanship and better design in the tools which the scientific investigator or teacher has to employ. The sporadic display of original or merely antique instruments (e.g. clocks) did little more than hint at an evolution of scientific knowledge, and fell far short of exhibiting in any adequately organised manner the actual progress of such evolution full as it was-and is-alike of human and philosophical interest.

Happily, we need not discuss the causes which hitherto prevented the realisation of an exhibition dealing with all branches of research by scientific experiment; whether the managers of international exhibitions have been deterred by lack of faith in the popularity of a section devoted to purely scientific exploration of the boundaries of knowledge, or by a too vivid realisation of the difficulties attendant upon the formation of such a collection as would worthily represent British achievements in the past and activities in the present. There is no need to debate the matter; visitors to the Science Court of the FrancoBritish Exhibition can see for themselves the fait accompli. Thanks to the initiative of Sir Norman Lockyer, supported by Sir William Mather and the executive committee, and backed with equal heartiness and ability by members of the British Science Guild, for the first time in the history of international exhibitions there has been brought together a collection of exhibits devoted to the illustration of methods and results of scientific research.

As chairman of the Science Section, Sir Norman Lockyer expressed regret that it has not been found possible to organise a French section, and we shall all echo this sentiment the more fully from seeing what an instructive display is contributed by the limited area of Great Britain and Ireland. By its very nature scientific investigation subordinates national rivalry to national cooperation, and anyone may point to the fact that no department could have attained its present state of efficiency had its progress not been furthered by the genius of the savants of France.

The catalogue, a closely printed volume of one hundred and ninety pages, has a permanent value for purposes of reference, and is sold for the moderate price of sixpence. No individual critic can do justice to all the departments represented, which are compendiously described as including instruments and methods used in and results obtained from the exploration of (I) the land; (2) the sea; (3) the air; (4) the heavens. Visitors will be impressed with the richness of the collection in apparatus and documents of historic interest, and with the complete subordination of the trading element. To indicate the character of this unique exhibition we give short notes on a few of the interesting features.

Heat.-The Manchester Municipal School of Technolog! lend Joule's laboratory note-books and MS. of researches, and his apparatus used for observing the heat-effects of compression and rarefaction of air. Portraits of Joule and some models of apparatus and reprints of papers are also shown. The physical department of the Imperial College of Science and Technology, South Kensington, exhibits modern appliances used in recent calorimetric, thermometric, and barometric determinations, including sunshine receivers and recorders. One recorder shown registers electrically to $I$ part in 10,000 the variations produced in a receiver distant a mile or more. With the platinum grid thermometer for determining the temperature of the air is shown a record obtained during the solar eclipse of August 30, 1905. The Cambridge Scientific Instrument Company show Boys's radiomicrometer, a Féry pyrometer, Callendar and Griffiths's bridge, \&c.

It will be seen that we have, on the one hand, the historic apparatus and documents, on the other, the methods and means of up-to-date research. This is typical. All the numerous sections into which the Science Court is divided and subdivided show the same contrast of ancient and modern research. As a consequence, the serious student will everywhere find interesting material, and it may well happen that he will learn more and get fresher views of his subject from the early investigators.

Magnetism and Electricity.-This is a strong department, the evolution of telegraphy in all its branches being particularly well illustrated. From the Wheatstone Laboratory of King's College, London, come the original Daniell's batteries, the original resistance box, bridge and chronograph of Wheatstone, while Sir William Preece and H.M. Postmaster-General contribute numerous specimens dating from 1837 to 1908 which present a miniature of progress in the electric transmission of signals. Signor Marconi sends thirty-three items, including some of the apparatus used in Newfoundland for the first Transatlantic reception in 1901. Much of the evolution of the AyrtonPerry instruments can be traced. The early and recent forms of lamp contributed by Sir J. W. Swan are particularly interesting. It is hardly necessary to say that Kelvin instruments find a place, as do the devices associated with the recent researches of H. A. Wilson, P. E. Shaw, Duddell, and Fleming. Dr. Shelford Bidwell shows his selenium cell, and attention will no doubt be attracted to his model of apparatus for transmitting pictures by telegraph, also dating from $\mathrm{I} 88 \mathrm{r}$.

Chemistry.-There is an excellent collection of preparations in connection with both physical and technical chemistry. Recent research is represented by contributions from the Davy-Faraday Research Laboratory, the Imperial College of Science, the University of Manchester, and many institutions and investigators too numerous to mention. Many will doubtless be interested in the apparatus used by Lord Rayleigh in the discovery of argon, and by Sir William Ramsay in his researches on helium and the new gases. The penetration of the physicist into the domain of the chemist is nicely illustrated by the inclusion of Sir Oliver Lodge's "ether machine" in the chemistry division. Magnificent specimens of salts of the platinum group were on view, lent by Messrs. Johnson, Matthey and Co. But of all the items in this division we were most attracted by (I) Black's original balance, dating from I766-the foundation-stone of modern chemistry; (2) original mauvein preparations made by the late Sir William Perkin between 1868 and 1872 . The general public may be expected to be interested in the "oldest lucifer matches," made by Walker, of Stockon-on-Tees, in 1827 ; also in the "chemistry of a bottle of eau de Cologne," contrasting natural and synthetic methods of production.

Metallography.-Micro-sections of metals prepared in 1863-4 by the late Dr. Sorby are shown; the remainder of the items illustrate modern developments of this branch of science, to further which a special institution was founded quite recently.

Biology.-The members of the biology subcommittee have secured an exhibit of profound interest from the Liverpool School of Tropical Medicine, which has sent specimens illustrating sleeping sickness, ngana, malaria,

No. 2016 , vor. 78 ] 